\title{
Corrigendum
}

Genome Research 25: 41-56 (2015)

Corrigendum: Characterization of the neural stem cell gene regulatory network identifies OLIG2 as a multifunctional regulator of self-renewal

Juan L. Mateo, Debbie L.C. van den Berg, Maximilian Haeussler, Daniela Drechsel, Zachary B. Gaber, Diogo S. Castro, Paul Robson, Q. Richard Lu, Gregory E. Crawford, Paul Flicek, Laurence Ettwiller, Joachim Wittbrodt, François Guillemot, and Ben Martynoga

The name of an author, Q. Richard Lu, was initially omitted from the authorship list of this article. The authors apologize for this oversight. Please note the corrected list above. The author and affiliation lists have already been corrected in both the PDF and full-text files online.

doi: 10.1101/gr.216044.116 


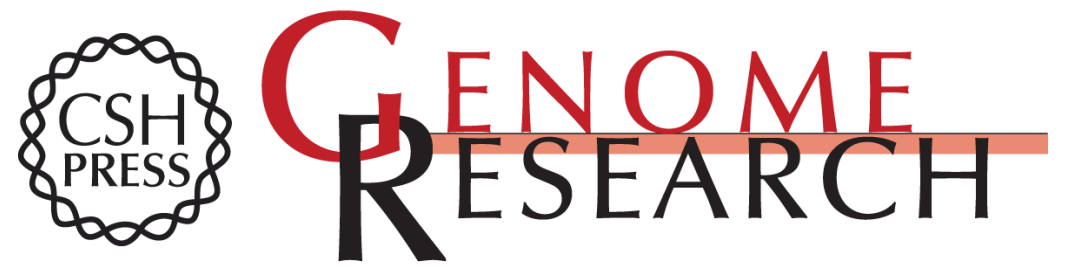

\section{Corrigendum: Characterization of the neural stem cell gene regulatory network identifies OLIG2 as a multifunctional regulator of self-renewal}

Juan L. Mateo, Debbie L.C. van den Berg, Maximilian Haeussler, et al.

Genome Res. 2016 26: 1626

Access the most recent version at doi:10.1101/gr.216044.116

\section{Related Content}

OLIG2 as a multifunctional regulator of self-renewal

Juan L. Mateo, Debbie L.C. van den Berg
Genome Res. January , 2015 25: 41-56

Open Access Freely available online through the Genome Research Open Access option.

License

Email Alerting

Service
Receive free email alerts when new articles cite this article - sign up in the box at the top right corner of the article or click here.

\section{Affordable, Accurate Sequencing.}

To subscribe to Genome Research go to:

https://genome.cshlp.org/subscriptions 